\section{Kovalchuk I., Tobilko V., Kholodko Yu., Zahorodniuk $\mathbf{N}$. Kornilovych B.}

\title{
PURIFICATION OF MINERALIZED WATERS FROM U(VI) COMPOUNDS USING BENTONITE/IRON OXIDE COMPOSITES
}

Об'єктом дослідження є бентонітові глини, основним породоутворюючим мінералом яких є монтморилоніт. Даний природний силікат проявляє сорбиійну здатність до іонів важких металів завдяки високій катіонообмінній ємності та питомій поверхні. Одним з найбільш проблемних місць використання монтморилоніту в сорбційних прощесах є здатність до набухання у водних середовищах. Це значно ускладнює відділення відпращьованого сорбенту від очищеної води. Для усунення даного недоліку найчастіше використовують гранулювання з подальшою термічною обробкою. При цьому в якості структуроутворюючого агенту застосовують різні полімерні сполуки. Такий прийом призводить до значного зменшення питомої поверхні бентонітових глин, а значить, і погіршення їх сорбційних властивостей. В ході дослідження використовували метод модифікування поверхні монтморилоніту оксигідроксидами феруму (феригідритом). Отримані матеріали відрізняються технологічністю та підвищеною сорбщійною здатністю по відношенню до сполук урану. Це пов'язано з тим, що при обробці поверхні бентонітових глин феригідритом можна отримати ефективні сорбенти, які втрачають здатність до набухання без термічної обробки. Нанесення шару ферумоксидних сполук на поверхню монтморилоніту привело до зміни параметрів поруватої структури отриманого композиту. Так, питома поверхня модифікованого зразку становить $250 \mathrm{м}^{2} / 2$, що значно перевищує таку для вихідного мінералу $\left(89 \mathrm{~m}^{2} / 2\right)$. При щьому у 2,8 рази збільшився середній розмір пор. Показано, що внаслідок обробки поверхні монтморилоніту феригідритом відбувається зростання сорбційної здатності матеріалів щодо сполук урану зі збільшенням вмісту заліза на поверхні: від 0,42 мг/ح для вихідного монтморилоніту до 10,13 мг/г для модифікованого зразку. Встановлено, що присутність конкурентних металів (As, Mn, Co, Cd, Cr) в мінералізованих водах в еквімолярних кількостях не призводить до суттєвої зміни величин адсорбиї урану на бентоніт/ферумоксидних композитах.

Ключові слова: очищення води, сорбція урану(VI), бентоніт, монтморилоніт, оксигідроксиди заліза, мінералізовані води, важкі метали.

Received date: 14.02 .200

Accepted date: 17.03 .2020

Published date: 30.06 .2020
Copyright (C) 2020, Kovalchuk I., Tobilko V., Kholodko Yu., Zahorodniuk N., Kornilovych B. This is an open access article under the CC BY license (http://creativecommons.org/licenses/by/4.0)

\section{Introduction}

The development of the uranium mining and uranium processing industries causes significant environmental pollution, in particular the water basin. Underground or aggregate leaching of uranium, the presence of waste storage facilities for hydrometallurgical processing of uranium ores lead to the entry into the groundwater and groundwater compounds of uranium and other heavy metals and radionuclides [1, 2].

The increased content of heavy metals and radionuclides in water poses a threat to human health [2, 3]. Uranium compounds are radioactive and quite chemically toxic, the accumulation of uranium in the kidneys leads to irreversible damage and poses a potential risk to life. According to world standards and the World Health Organization (WHO) classification, uranium is a carcinogenic element. The level of its concentration in water should not exceed $30 \mu \mathrm{g} / \mathrm{dm}^{3}$ according to WHO recommendations [4], $30 \mu \mathrm{g} / \mathrm{dm}^{3}$ in accordance with the standards of the US Environmental Protection Agency [5] and $40 \mu \mathrm{g} / \mathrm{dm}^{3}$ in accordance with the State Standards of Ukraine [6].
Uranium in a natural aqueous medium is dissolved in a hexavalent state both in positively charged forms of the uranyl cation $\mathrm{UO}_{2}^{2+}$ and in the form of hydroxyl complexes, for example, $\mathrm{UO}_{2} \mathrm{OH}^{+}$, and in neutral $\mathrm{UO}_{2}(\mathrm{OH})_{2}, \mathrm{UO}_{2} \mathrm{CO}_{3}$ and negatively charged forms $\left(\mathrm{UO}_{2}\right)_{2} \mathrm{CO}_{3}(\mathrm{OH})_{3}^{-}$. In the tetravalent state, uranium is much less soluble [7, 8]. As a result of the use of acid leaching in hydrometallurgical processes, in addition to the high content of U(VI) compounds, groundwater in places of uranium ore mining and processing is characterized by increased mineralization, which amounts to several grams per liter [9]. In such waters, $\mathrm{U}(\mathrm{VI})$ is predominantly in the form of negatively charged sulfate or carbonate complexes [10], while the solubility of uranium in mineralized waters increases [8]. Heavy metals and radionuclides, which are also present in contaminated mineralized waters [11], mutually affect the solubility of uranium and each other.

The removal of heavy metals and uranium from wastewater is carried out using reagent methods, membrane separation methods and their combination: deposition, oxidation, coagulation, ultrafiltration, reverse osmosis, etc. However, 
only the sorption method ensures the removal of uranium and heavy metals from polluted waters to the very low levels that can't be achieved using other methods.

Various materials are used to remove uranium, such as activated carbon, synthetic resins, zeolites, materials of biological origin, etc. Synthetic sorption materials have a high efficiency of removing inorganic toxicants, but their disadvantage is their high cost and multi-stage synthesis. The use of clays as sorbents is promising given the various possibilities of modifying their surface to create functional materials with new improved properties. Surface treatment of clay minerals with iron oxides and hydroxides increases their adsorption capacity with respect to inorganic toxicants [12, 13]. Moreover, the obtained sorbents have both anion-exchange and cation-exchange properties.

Therefore, the development of composites based on natural clay minerals by modifying them with iron compounds for the effective extraction of uranium compounds and other inorganic toxicants from contaminated mineralized waters is a timely and relevant task, and is the subject of this research.

\section{The object of research and its technological audit}

The object of research is bentonite clays, the main mineral of which is montmorillonite - a clay mineral with a layered structure. Montmorillonite forms a 2:1 type structure with two tetrahedral and octahedral layers between them, its structural formula is $\mathrm{Al}_{3} \mathrm{Mg}\left[\mathrm{Si}_{4} \mathrm{O}_{10}\right](\mathrm{OH})_{2} \cdot n \mathrm{H}_{2} \mathrm{O}$ [14]. Water molecules located in the interlayer space of montmorillonite lead to the lid of structural packets. The active $\mathrm{Al}(\mathrm{Si}) \mathrm{OH}$ groups are located mainly on the lateral faces of montmorillonite and are the main factors contributing to the sorption of heavy metal cations and radionuclides.

A technological audit shows that natural clays, and in particular, bentonite, are widely used as sorbents in technological processes of water purification from inorganic toxicants found in cationic forms in waters. The surface of clay particles is predominantly negatively charged and therefore heavy metals and radionuclides that are in anionic form are not adsorbed on it. The sorption properties of clay minerals can be significantly improved by modifying their surface. Therefore, silicates, the surface of which is modified with various organic and inorganic compounds, are very promising for the removal of trace amounts of heavy metals and radionuclides from contaminated aqueous media.

\section{The aim and objectives of research}

The aim of research is to obtain bentonite/iron oxide composites for the extraction of uranium and heavy metals from polluted waters. Research objectives:

1. Synthesize bentonite/iron oxide composites and study their physicochemical characteristics.

2. To study the features of the sorption purification of contaminated mineralized waters from uranium and heavy metals by synthesized bentonite/iron oxide compounds.

\section{Research of existing solutions of the problem}

The removal of uranium compounds from polluted waters is carried out by various methods. One of them is chemical precipitation, oxidation, and coagulation methods that require the use of chemical reagents $[15,16]$. Membrane separation methods are also widely used, including ultrafiltration, nanofiltration, and reverse osmosis [17, 18]. However, sorption technologies are the most effective in treating water from heavy metals. To date, a large number of sorbents of various nature and origin, in particular synthetic materials, are developed [19, 20]. Sorbents based on zeolites and natural clay minerals are also obtained [21, 22]. Biosorbents are actively developed, for which algae and microorganisms are the raw material [23, 24]. Particular attention in the literature is given to studying the latest sorption materials for the extraction of inorganic toxicants $[25,26]$ primarily because only through sorption methods can high levels of purification of polluted waters is achieved.

The prospects of using sorbents based on iron and its compounds for the extraction of uranium and heavy metals from polluted waters are described in a significant number of works. The use of micro- and nanoscale iron in the processes of sorption extraction of uranium is studied [27, 28]. The effectiveness of water purification from natural radionuclides on iron oxides is also studied [29, 30]. Significant sorption ability with respect to uranium compounds is exhibited by (oxy) iron hydroxides (III) [31, 32]. High sorption properties of iron compounds indicate the possibility of creating the latest sorption materials based on them. Ferric oxides (for example, ferrihydrite, goethite and hematite) effectively remove uranium (VI) compounds and heavy metals from water in a neutral medium [13]. However, the drawback of such sorbents is the ability to aggregate particles during synthesis [33, 34]. The application of the reaction layer of ferrum compounds to special substrates (clay minerals, activated carbon, ion-exchange resins, etc.) makes it possible to increase the aggregative stability of materials [31]. Thus, the sorbents obtained by depositing iron oxides and hydroxides on the surface of clay minerals have enhanced sorption properties for uranium and heavy metals due to the cation exchange ability of clay minerals and the anion exchange properties of supported iron compounds.

Thus, the development of bentonite/iron oxide composites will make it possible to obtain material based on cheap natural raw materials with improved structural and sorption characteristics. The study of the conditions for the effective extraction of uranium from contaminated waters on bentonite modified with iron compounds is carried out taking into account the peculiarities of sorption of uranium in mineralized waters, the presence of arsenic, manganese, cobalt, cadmium, chromium compounds in the solution.

\section{Methods of research}

The synthesis of bentonite/iron oxide composites was carried out by treating the surface of montmorillonite (MMT) with iron salts (III) according to a modified procedure [35]. To do this, in a $0.2 \mathrm{M}$ solution of $\mathrm{Fe}\left(\mathrm{NO}_{3}\right)_{3} \cdot 9 \mathrm{H}_{2} \mathrm{O}$, a weighed silicate was introduced in various mass ratios of $\mathrm{Fe}(\mathrm{g})$ : clay mineral $(\mathrm{g})-0.01: 1 ; 0.05: 1 ; 0.1: 1$ and $1: 1$ to obtain samples of bentonite/iron oxide composites Fh-MMT 0.01-1; Fh-MMT 0.05-1; Fh-MMT 0.1-1; Fh-MMT 1-1. The suspension was stirred for $1 \mathrm{~h}$, after which a $1 \mathrm{M} \mathrm{KOH}$ solution was added to $\mathrm{pH} 7-8$. The resulting precipitate was washed with distilled water from excess salts, sedimented and filtered under vacuum. The resulting samples were dried at $80{ }^{\circ} \mathrm{C}$ in an oven, triturated and sieved to obtain a fraction of $\leq 0.2 \mathrm{~mm}$. Samples were stored in containers without air. 
The structure of the initial and modified samples was studied by diffraction (X-ray phase analysis (XRD)) using oriented preparations using a DRON-4-07 diffractometer manufactured by the USSR (2-60 $2 \theta$, CuK $\alpha$ radiation).

To determine the parameters of the porous structure of montmorillonite and iron oxide composites, the method of low-temperature nitrogen adsorption-desorption (Quantachrome Nova 2200e Surface Area and Pore Size Analyzer, United States) was used. Samples were evacuated at room temperature for 30 minutes and kept for 5 minutes after equilibrium is established at each point of the isotherm. The specific surface area and total pore volume were determined by the Brunauer, Emmett, and Teller (BET) methods, and the pore size distribution was determined by the Barrett-Joyner-Halenda (BJH) method [36].

The size of aggregates in clay samples and the $\zeta$ potential were determined using the Zetasizer Nano ZS Malvern Instrument (United Kingdom) according to the Henry equation using the Oshima approximation [37, 38].

Water purification from pollution by uranium (VI) compounds using bentonite/iron oxide composites was studied in a wide range of concentrations. To prepare aqueous solutions of uranium (VI), the uranyl sulfate salt $\mathrm{UO}_{2} \mathrm{SO}_{4} \cdot 3 \mathrm{H}_{2} \mathrm{O}$ (concentration $10^{-2} \mathrm{M}$ ) was used.

The study of the processes of sorption purification of contaminated water was carried out using solutions whose composition according to the main anionic components corresponded to the composition of underground saline water at the liquid waste storage facility for processing uranium ores of the Eastern Mining and Processing Combine (Zhovti Vody, Ukraine): $\mathrm{HCO}_{3}^{-}-450, \mathrm{Cl}^{-}-180, \mathrm{SO}_{4}^{2-}-2830$, $\mathrm{NO}_{3}^{-}-130 \mathrm{mg} / \mathrm{dm}^{3}[9]$. The output solutions were prepared on the basis of the corresponding sodium salts, the total salt content was $5200 \mathrm{mg} / \mathrm{dm}^{3}$, pH 7.2. The $\mathrm{pH}$ value of water systems was adjusted with $0.1 \mathrm{M} \mathrm{NaOH}$ solution and monitored with a $\mathrm{pH}$-meter $\mathrm{pH}-150 \mathrm{M}$ (Republic of Belarus).

Sorption extraction of uranium (VI) bentonite/iron oxide composites was carried out under static conditions at room temperature. The volume of the aqueous phase was $50 \mathrm{~cm}^{3}$, the weighed portion of the sorbent was $0.1 \mathrm{~g}$. To establish adsorption equilibrium, the samples were continuously shaken for $1 \mathrm{~h}$. The solid and liquid phases were separated by centrifugation $(6000 \mathrm{rpm})$. The uranium (VI) content in the solutions after sorption was determined spectrophotometrically using a UNICO-UV 2100 spectrophotometer (USA) using an Arsenazo III reagent at a wavelength of $665 \mathrm{~nm}$.

The value of the sorption of uranium (VI) a (mg/g) was calculated by the formula:

$$
a=\left(C_{\text {init }}-C_{e q}\right) \cdot V / m,
$$

where $C_{i n i t}, C_{e q}$ - initial and equilibrium metal concentration, $\mathrm{mg} / \mathrm{dm}^{3} ; V$ - volume of the solution, $\mathrm{dm}^{3} ; m-$ mass of the sorbent sample, $g$.

The experimental isotherms of sorption of uranium (VI) were processed using the Langmuir mathematical model for a homogeneous surface [39]:

$$
C_{e q} / a_{e q}=1 /\left(K_{L} \cdot a_{m}\right)+\left(1 / a_{m}\right) \cdot C_{e q},
$$

where $a_{e q}$ - equilibrium sorption, mg/g; $K_{L}-$ Langmuir constant, characterizing the energy of sorption, $\mathrm{dm}^{3} / \mathrm{mg}$; $C_{e q}$ - equilibrium concentration, $\mathrm{mg} / \mathrm{dm}^{3} ; a_{m}$ - sorption capacity of the monolayer, $\mathrm{mg} / \mathrm{h}$.
And also Freundlich models for a heterogeneous surface [40]:

$$
\lg a_{e q}=\lg K_{F}+(1 / n) \cdot \lg C_{e q},
$$

where $K_{F}-$ Freundlich constant characterizing the sorption capacity, $\mathrm{dm}^{3} / \mathrm{h} ; 1 / n$ - Freundlich constant, which characterizes the intensity of sorption.

The distribution of the forms of the presence of U(VI), $\mathrm{Cd}(\mathrm{II}), \mathrm{Co}(\mathrm{II}), \mathrm{Cr}(\mathrm{VI}), \mathrm{Mn}(\mathrm{II}), \mathrm{As}(\mathrm{V})$ cations in solution was calculated using the Medusa software [41].

Sorption of uranium (VI) extraction is iron oxide composites from mineralized waters in the presence of other cations Cd(II), Co(II), Cr(VI), Mn(II), As(V) were studied under conditions of their equimolar content in solution (ratio of uranium (VI)/Me 1:1) at a concentration of $10^{-4} \mathrm{M}, \mathrm{pH} 7.2$, mineralization $5.2 \mathrm{~g} / \mathrm{dm}^{3}$. Aqueous solutions of heavy metal salts were prepared using the corresponding salts $\mathrm{Na}_{2} \mathrm{HAsO}_{4} \cdot 7 \mathrm{H}_{2} \mathrm{O}, \mathrm{CoCl}_{2} \cdot 6 \mathrm{H}_{2} \mathrm{O}$, $\mathrm{K}_{2} \mathrm{Cr}_{2} \mathrm{O}_{7}, \mathrm{MnCl}_{2} \cdot 4 \mathrm{H}_{2} \mathrm{O}, \mathrm{Cd}\left(\mathrm{NO}_{3}\right)_{2} \cdot 4 \mathrm{H}_{2} \mathrm{O}$ (concentration $10^{-2} \mathrm{M}$ ). The equilibrium concentration of each metal in solution was determined by inductively coupled plasma atomic absorption spectrometry (Thermo Scientific iCAP 7400 ICP-OES, USA).

The degree of water purification (\%) from U(VI), $\mathrm{Cd}(\mathrm{II}), \mathrm{Co}(\mathrm{II}), \mathrm{Cr}(\mathrm{VI}), \mathrm{Mn}(\mathrm{II}), \mathrm{As}(\mathrm{V})$ was calculated by the formula:

$$
C O=\left(C_{\text {init }}-C_{e q}\right) / C_{\text {init }} \cdot 100,
$$

where $C_{i n i t}, C_{e q}$ - initial and equilibrium metal concentration, $\mathrm{mg} / \mathrm{dm}^{3}$.

\section{Research results}

Fig. 1 shows the diffraction patterns of iron oxide composites (Fh-MMT) with different ratios of ferrihydrite and output bentonite (MMT).

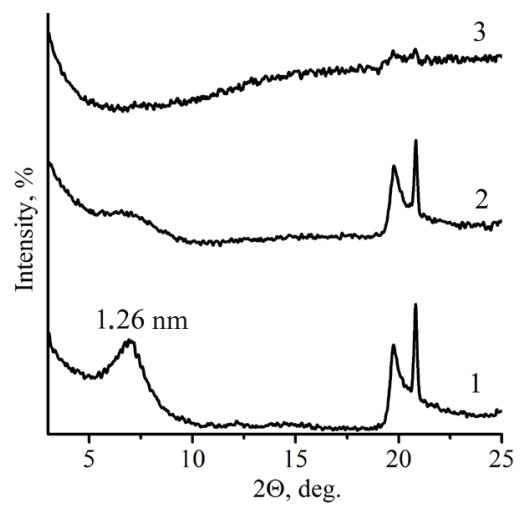

Fig. 1. Diffraction patterns of 1 - initial (MMT) and

2, 3 - modified bentonite: 2 - (Fh-MMT 0.05-1), 3 - (Fh-MMT 1-1)

The bentonite diffraction pattern shows an intense basal reflection $d_{001}=1.26 \mathrm{~nm}$, which is typical for air-dried samples of the main mineral of bentonite clays - montmorillonite [42]. The diffraction patterns of Fh-MMT 0.05-1 (curve 2) are very similar to those for MMT, but the $d_{001}$ reflection is less intense, which suggests that some of the added $\mathrm{Fe}$ (III) is located in the interlayer space of montmorillonite [43]. The practical X-ray amorphism of the Fh-MMT 1-1 sample can be explained by the presence of ferric iron in the interlayer space of montmorillonite. It can 
also be explained by the formation of ferrihydrite on the surface of montmorillonite in the form of thin films or very small clusters, or particles (iron oxide/nanoparticle co-aggregates), which, according to existing literature data [44], have an average size of $6 \mathrm{~nm}$.

As can be seen from Fig. 2, the nature of the nitrogen adsorption - desorption isotherm on the starting montmorillonite is typical of microporous sorbents, the hysteresis loop is weakly expressed, and according to the Brunauer, Emmett, and Teller (BET) classification, it belongs to the first type of isotherms [45].

For modified montmorillonite samples, the shape of the hysteresis loops in accordance with the recommendations of IUPAC (International Union of Pure and Applied Chemistry) is of H2 type, which is characterized by slitshaped pores with flat parallel walls.

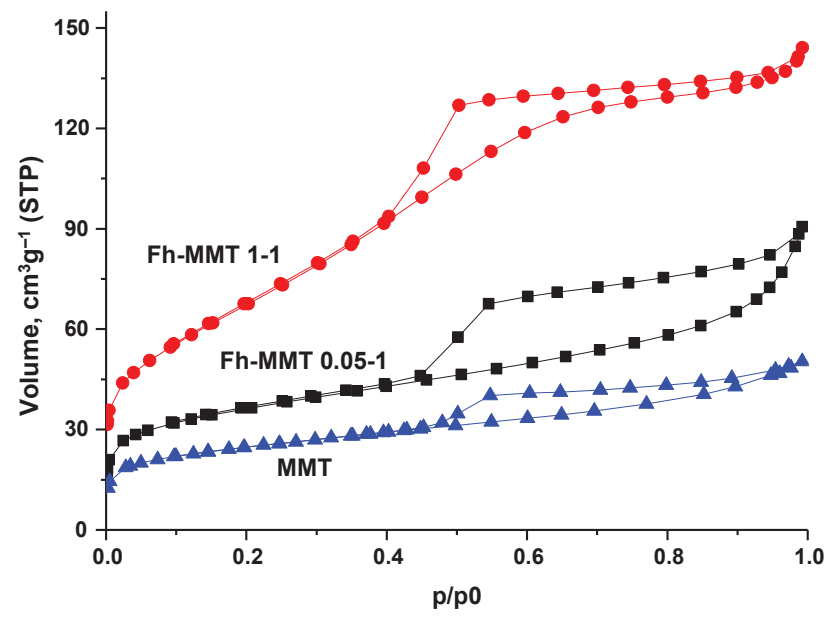

Fig. 2. Nitrogen sorption-desorption isotherms on the initial (MMT) and modified bentonite (Fh-MMT 0.05-1), (Fh-MMT 1-1)

Table 1 shows the parameters of the porous structure of the samples (specific surface area $S, \mathrm{~m}^{2} / \mathrm{g}$, total pore volume $V_{\Sigma}, \mathrm{cm}^{3} / \mathrm{h}$, micropore volume $V_{\mu}, \mathrm{cm}^{3} / \mathrm{g}$ and pore size distribution $r_{1}, r_{2}, \mathrm{~nm}$ ).

An analysis of the parameters of the porous structure according to the results of low-temperature adsorption-desorption of nitrogen at $77 \mathrm{~K}$ of bentonite/iron oxide composite materials indicates that, during the deposition of ferrihydrite on the surface of silicate, the total specific surface of the obtained sorbent increases to $250 \mathrm{~m}^{2} / \mathrm{g}$. This is 2.8 times higher than the total specific surface area for a natural mineral, while the pore volume also increases by 2.8 times.

Fig. 3 shows the character of the dependence of the $\zeta$ potential on the $\mathrm{pH}$ of the medium obtained by measuring the electrokinetic parameters of the particles in the dispersions of the output and bentonite modified with ferrihydrite.

Characterization of the porous structure of the initial and modified samples

\begin{tabular}{|c|c|c|c|c|c|c|}
\hline \multirow{3}{*}{ Sample } & \multirow{3}{*}{$5, \mathrm{~m}^{2} / \mathrm{g}$} & \multirow{3}{*}{$V_{\Sigma}, \mathrm{cm}^{3} / \mathrm{g}$} & \multirow{3}{*}{$V_{\mu} \mathrm{cm}^{3} / g$} & \multirow{3}{*}{$V_{\mu \%,} \%$} & \multirow{2}{*}{\multicolumn{2}{|c|}{$\begin{array}{c}\text { Pore size distribution, nm } \\
\mathrm{BJH} \mathrm{d} V(\Gamma)\end{array}$}} \\
\hline & & & & & & \\
\hline & & & & & $\Gamma_{1}$ & $\Gamma_{2}$ \\
\hline MMT & 89 & 0.081 & 0.016 & 19.80 & 1.41 & - \\
\hline Fh-MMT 0.05-1 & 128 & 0.141 & 0.048 & 34.04 & 1.54 & 1.92 \\
\hline Fh-MMT 1-1 & 250 & 0.224 & 0.095 & 42.41 & 1.70 & 1.72 \\
\hline
\end{tabular}

The $\zeta$ potential for the initial sample in the entire $\mathrm{pH}$ range is negative and amounts to $(-20)-(-70) \mathrm{mV}$. This is due to the developed double electric layer (DEL) of exchange cations at negatively charged basal surfaces of planar mineral particles [46]. The $\mathrm{pH}$ dependence of the $\zeta$ potential for samples modified by ferrihydrite repeats that for the initial samples, but the $\zeta$ potential increases by $30-40 \mathrm{mV}$ over the entire $\mathrm{pH}$ range and amounts to (7) $-(-38) \mathrm{mV}$.

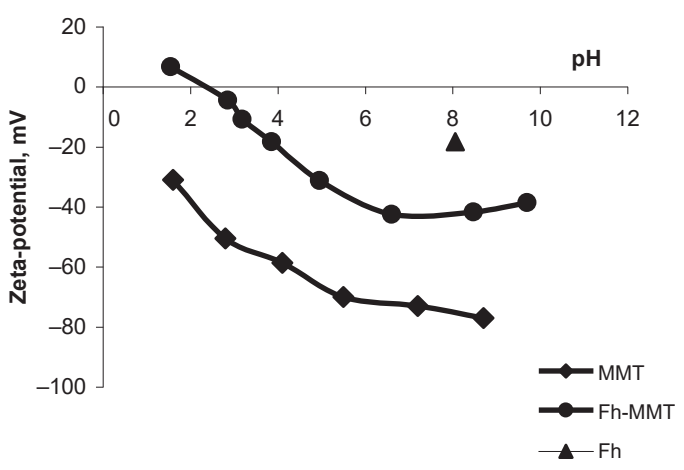

Fig. 3. The dependence of the zeta potential of the output (MMT) and modified samples (Fh-MMT 1-1) on $\mathrm{pH}$

The values of the hydrodynamic diameter of the particles in the solution are given in Table 2 . The data presented indicate a significant polydispersity of systems. In the output samples, particles with a diameter of $\sim 570 \mathrm{~nm}$ and $\sim 4900 \mathrm{~nm}$, with a predominance of small particles, predominate. Clay modification with ferrihydrite leads to an increase in particle size to $\sim 1600 \mathrm{~nm}$ and $\sim 5000 \mathrm{~nm}$.

Table 2

The value of the hydrodynamic particle diameter (d) obtained by the distribution of particle size by intensity according to dynamic light scattering and the polydispersity coefficient $(P \mathrm{~d} l)$ in solution

\begin{tabular}{|c|c|c|}
\hline Sample & $d, \mathrm{~nm}$ & $P \mathrm{~d} I$ \\
\hline MMT & $(57 \pm 2) \cdot 10^{1},(49 \pm 3) \cdot 10^{2}$ & $0.36 \pm 0.02$ \\
\hline Fh & $(14 \pm 2) \cdot 10^{2},(53 \pm 2) \cdot 10^{2}$ & $0.51 \pm 0.09$ \\
\hline Fh-MMT & $(16 \pm 2) \cdot 10^{2},(50 \pm 4) \cdot 10^{2}$ & $0.41 \pm 0.06$ \\
\hline
\end{tabular}

Fig. 4 shows the sorption isotherms of uranium (VI) bentonite/iron oxide composites and the output sample at $\mathrm{pH} 7.2$ from mineralized waters. The data obtained indicate that, upon modifying the surface of montmorillonite iron oxide-hydroxides, the sorption ability of the obtained samples with respect to uranium (VI) increases in the series MMT<Fh-MMT 0.01-1<Fh-MMT 0.05-1< $<$ Fh-MMT 0.1-1<Fh-MMT $1-1$ in accor-

Table 1 dance with the increase in iron content.

It is known that for clay minerals, in particular montmorillonite, which are cation exchangers, sorption extraction occurs due to the binding of ions $\mathrm{UO}_{2}^{2+}$ mainly in the active centers of the side faces (aluminol $=\mathrm{Al}-\mathrm{OH}$, silanol $=\mathrm{Si}-\mathrm{OH}$ or bridging groups $=\mathrm{Al}-\mathrm{OH}-\mathrm{Si}=$ ). The negative charge of the surface of montmorillonite prevents the adsorption of negatively charged anionic forms of metals on this 
surface. For modified samples, even with a low content of iron compounds on the surface, there is an increase in the values of sorption extraction of uranium. Such high values of uranium sorption for samples Fh-MMT 0.1-1 and Fh-MMT 1-1 can be explained by the presence of ferric iron in the interlayer space of montmorillonite and the formation of ferrihydrite on the surface of montmorillonite, which leads to the formation of active centers capable of anion exchange $=\mathrm{Fe}-\mathrm{OH}[43]$.

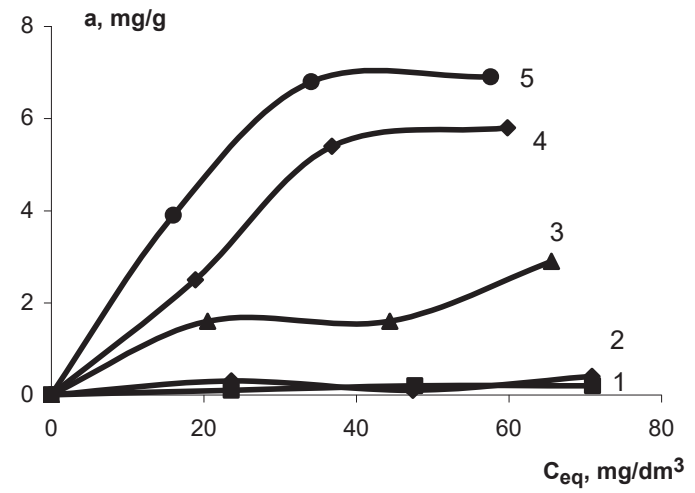

Fig. 4. The sorption isotherm of U(VI) from mineralized water at 1 - output (MMT) and 2-5 - modified samples: 2 - (Fh-MMT 0.01-1), 3 - (Fh-MMT 0.05-1), 4 - (Fh-MMT 0.1-1), 5 - (Fh-MMT 1-1)

Sorption isotherms were analyzed using the Langmuir and Freindlich equations and the calculation results for the corresponding coefficients are given in Table 3 .

The obtained isotherms are described by the Langmuir monomolecular sorption equation for a homogeneous surface (correlation coefficients $R^{2}=0.9386 \div 0.976$ ) and the empirical Freindlich equation of sorption on a heterogeneous surface, (correlation coefficients $R^{2}=0.941 \div 0.9915$ ). The maximum sorption values $A_{\max }$ of uranium (VI) compounds from mineralized waters are observed for samples with a high degree of surface coating with ferrihydrite (Fh-MMT 1-1), these values are $10.13 \mathrm{mg} / \mathrm{g}$, while for the output montmorillonite they are $0.42 \mathrm{mg} / \mathrm{g}$.

The sorption extraction of heavy metals and, in particular, uranium from aqueous solutions is significantly affected by the presence of ion-borne forms of metals in these solutions. Using the Medusa program, it was determined that for uranium in waters with high salinity, the main forms in the acidic region are sulfate complexes $\mathrm{UO}_{2} \mathrm{SO}_{4}$ and $\mathrm{UO}_{2}\left(\mathrm{SO}_{4}\right)_{2}^{2-}$, and in the neutral and alkaline regions, carbonate complexes $\mathrm{UO}_{2} \mathrm{CO}_{3}, \mathrm{UO}_{2}\left(\mathrm{CO}_{3}\right)_{2}^{2-}$ and $\mathrm{UO}_{2}\left(\mathrm{CO}_{3}\right)_{3}^{4-}$

Mineralized waters at the liquid waste storage facility for uranium ore processing contain cations of other metals. Therefore, the features of sorption of uranium from mineralized waters on iron oxide composites were studied under conditions of equimolar contents of uranium (VI) and cadmium (II), cobalt (II) cations, chromium (VI), manganese (II), arsenic (V). The distribution of various forms of these metals in the studied solutions (concentration of $10^{-4} \mathrm{M}$ in solution, mineralization of $5.2 \mathrm{~g} / \mathrm{l}$ and $\mathrm{pH}$ of 7.2 ) are given in Table 4 .

Table 4

Distribution of the forms of coexisting cations U(VI), Cd(II), $\mathrm{Co}(\mathrm{II}), \mathrm{Cr}(\mathrm{VI}), \mathrm{Mn}(\mathrm{II}), \mathrm{As}(\mathrm{V})$ in saline waters

\begin{tabular}{|c|c|c|}
\hline Form & $\begin{array}{l}\text { Content, \% } \\
\text { (for each Me) }\end{array}$ & $\begin{array}{c}\text { Content, \% } \\
\text { (of the total metal content) }\end{array}$ \\
\hline $\mathrm{UO}_{2} \mathrm{CO}_{3}$ & 2 & 0.3 \\
\hline$\left(\mathrm{UO}_{2}\right)_{2} \mathrm{CO}_{3}(\mathrm{OH})_{3}^{-}$ & 15 & 2.5 \\
\hline$\left(\mathrm{UO}_{2}\right)_{2}\left(\mathrm{CO}_{3}\right)_{2}^{2-}$ & 45 & 7.5 \\
\hline$\left(\mathrm{UD}_{2}\right)_{2}\left(\mathrm{CO}_{3}\right)_{3}^{4-}$ & 43 & 7.2 \\
\hline $\mathrm{H}_{2} \mathrm{AsO}_{4}^{-}$ & 25 & 4.2 \\
\hline $\mathrm{HAsO}_{4}^{2-}$ & 75 & 12.5 \\
\hline $\mathrm{CdCO}_{3}(\mathrm{c})$ & 98 & 16.3 \\
\hline $\mathrm{CdSO}_{4}$ & 2 & 0.3 \\
\hline $\mathrm{CoSO}_{4}$ & 78 & 13 \\
\hline $\mathrm{Ca}^{2+}$ & 18 & 3 \\
\hline $\mathrm{CoCO}_{3}(\mathrm{~s})$ & 4 & 0.7 \\
\hline $\mathrm{HCr}_{4}^{-}$ & 12 & 2 \\
\hline $\mathrm{NaCr}_{4}^{-}$ & 21 & 3.5 \\
\hline $\mathrm{Cr}_{4}^{2-}$ & 67 & 11.2 \\
\hline $\mathrm{MnCO}_{3}(\mathrm{c})$ & 88 & 14.7 \\
\hline $\mathrm{MnSO}_{4}$ & 8 & 1.3 \\
\hline $\mathrm{Mn}^{2+}$ & 3 & 0.5 \\
\hline $\mathrm{MnHCO}_{3}^{+}$ & 1 & 0.2 \\
\hline
\end{tabular}

Experiments on the sorption extraction of uranium (VI) from mineralized waters in the presence of coexisting cations $\mathrm{Cd}(\mathrm{II}), \mathrm{Co}(\mathrm{II}), \mathrm{Cr}(\mathrm{VI}), \mathrm{Mn}(\mathrm{II}), \mathrm{As}(\mathrm{V})$ show that the presence of the latter in solution (in equimolar amounts in relation to uranium) does not significantly affect the sorption value. This allows not to take into account their influence on sorption processes in the approximate calculation of the corresponding technological processes.

Table 3

Coefficients of the Freundlich and Langmuir equations for isotherms of sorption of uranium (VI) compounds from mineralized waters

\begin{tabular}{|c|c|c|c|c|c|c|}
\hline \multirow{2}{*}{ Sample } & \multicolumn{3}{|c|}{ Langmuir } & \multicolumn{3}{c|}{ Freundlich } \\
\cline { 2 - 7 } & $a_{m \prime} \mathrm{mg} / \mathrm{g}$ & $K_{L \prime} \mathrm{dm}^{3} / \mathrm{mg}$ & $R^{2}$ & $K_{F} \mathrm{dm}^{3} / \mathrm{g}$ & $1 / n$ & $R^{2}$ \\
\hline MMT & 0.42 & 0.039 & 0.976 & 0.06 & 2.52 & 0.941 \\
\hline Fh-MMT 0.01-1 & 0.28 & 0.0393 & 0.963 & 0.024 & 0.5374 & 0.968 \\
\hline Fh-MMT0.1-1 & 3.54 & 0.0389 & 0.971 & 0.362 & 0.4738 & 0.9897 \\
\hline Fh-MMT 0.5-1 & 9.89 & 0.0262 & 0.9386 & 0.396 & 0.7033 & 0.9801 \\
\hline Fh-MMT 1-1 & 10.13 & 0.0418 & 0.9642 & 0.392 & 0.7965 & 0.9915 \\
\hline
\end{tabular}

\section{SWOT analysis of research results}

Strengths. The main advantage of using iron oxide composites based on natural clay minerals to purify water from pollution by uranium compounds is their environmental friendliness, low cost, accessibility and manufacturability. Similar sorption materials are obtained using complex synthesis schemes and expensive chemicals, which significantly increases their cost.

Weaknesses. When using reagents based on iron (III) salts with a high degree of purity 
in the synthesis of bentonite/iron oxide composites, the cost of the synthesis product increases.

Opportunities. The use of bentonite/iron oxide composites for the extraction of uranium (VI) from complex aqueous systems, including solutions with high salinity and the presence of competing metals, is a promising area in environmental chemistry. The development of the technology of granulation of iron oxide composites will allow for the effective removal of sorption materials and the subsequent reliable disposal of waste water.

Threats. The presence on the world market of highly effective, but expensive sorption materials based on ionexchange resins, activated carbon, synthetic metal oxides creates a fairly strong competitive environment.

\section{Conclusions}

1. By treating the surface of montmorillonite with ferric compounds, bentonite/iron oxide composites are obtained. The application of the ferrihydrite layer on the surface of montmorillonite led to a change in the parameters of the porous structure of the obtained material, namely, an increase in the specific surface from $89 \mathrm{~m}^{2} / \mathrm{g}$ to $250 \mathrm{~m}^{2} / \mathrm{g}$ and an increase in the average pore size to $1.72 \mathrm{~nm}$. The $\mathrm{X}$-ray amorphous nature of the obtained bentonite/iron oxide composites, a change in their electrokinetic properties and an increase in dispersion due to modification indicate the presence of iron oxide-hydroxide (III) on the surface of montmorillonite.

2. The features of sorption removal of uranium compounds from mineralized waters using the obtained bentonite/iron oxide composites are studied. It is shown that as a result of surface modification of montmorillonite by ferric compounds, the sorption capacity of materials for uranium compounds increases with an increase in the iron content on the surface: from $0.42 \mathrm{mg} / \mathrm{g}$ for montmorillonite to $10.13 \mathrm{mg} / \mathrm{g}$ for modified montmorillonite. It is found that the presence of competitive metals (As, Mn, $\mathrm{Co}, \mathrm{Cd}, \mathrm{Cr}$ ) in mineralized waters in equimolar amounts does not lead to a significant change in the values of uranium adsorption on bentonite/iron oxide composites.

\section{References}

1. Kornilovych, B. Yu., Sorokin, O. H., Pavlenko, V. M., Koshyk, Yu. Y. (2011). Pryrodookhoronni tekhnolohii v uranovydobuvnii ta pererobnii promyslovosti. Kyiv, 156.

2. Liu, B., Peng, T., Sun, H., Yue, H. (2017). Release behavior of uranium in uranium mill tailings under environmental conditions. Journal of Environmental Radioactivity, 171, 160-168. doi: http://doi.org/10.1016/j.jenvrad.2017.02.016

3. Merkel, B., Schipek, M. (2011). The New Uranium Mining Boom. Berlin, Heidelberg: Springer, 848. doi: http://doi.org/10.1007/9783-642-22122-4

4. Guidelines for Drinking-water Quality. Fourth Edition. Recommendation (2011). World Health Organization. WHO, 564. Available at: https://apps.who.int/iris/bitstream/handle/10665/44584/ 9789241548151_eng.pdf;jsessionid=27986ECA8EB82D1198DAE D796EC75484? sequence $=1$

5. Drinking Water Requirements for States and Public Water Systems. Available at: https://www.epa.gov/dwreginfo

6. NRBU-97. Derzhavni hihiienichni normatyoy. Normy radiatsiinoi bezpeky Ukrainy (1997). Kyiv, 131.

7. Langmuir, D. (1978). Uranium solution-mineral equilibria at low temperatures with applications to sedimentary ore deposits. Geochimica et Cosmochimica Acta, 42 (6), 547-569. doi: http:// doi.org/10.1016/0016-7037(78)90001-7

8. Langmuir, D. (1997). Aqueous Environmental Geochemistry. New York: Prentice Hall, 603.
9. Kornilovych, B., Wireman, M., Ubaldini, S., Guglietta, D., Koshik, Y., Caruso, B., Kovalchuk, I. (2018). Uranium Removal from Groundwater by Permeable Reactive Barrier with Zero-Valent Iron and Organic Carbon Mixtures: Laboratory and Field Studies. Metals, 8 (6), 408. doi: http://doi.org/10.3390/met8060408

10. Kovalchuk, I. A., Pylypenko, I. V., Kornilovych, B. Yu., Bashchak, O. Ye. (2019). Sorbtsiine ochyshchennia mineralizovanykh pidzemnykh vod vid spoluk uranu z vykorystanniam pilarovanykh hlyn. Dopovidi Natsionalnoi akademii nauk Ukrainy, 10, 80-88.

11. Hashim, M. A., Mukhopadhyay, S., Sahu, J. N., Sengupta, B (2011). Remediation technologies for heavy metal contaminated groundwater. Journal of Environmental Management, 92 (10), 2355-2388. doi: http://doi.org/10.1016/j.jenvman.2011.06.009

12. Nekhunguni, P. M., Tavengwa, N. T., Tutu, H. (2017). Sorption of uranium(VI) onto hydrous ferric oxide-modified zeolite: Assessment of the effect of $\mathrm{pH}$, contact time, temperature, selected cations and anions on sorbent interactions. Journal of Environmental Management, 204, 571-582. doi: http://doi.org/ 10.1016/j.jenvman.2017.09.034

13. Jung, H. B., Xu, H., Konishi, H., Roden, E. E. (2016). Role of nano-goethite in controlling U(VI) sorption-desorption in subsurface soil. Journal of Geochemical Exploration, 169, 80-88. doi: http://doi.org/10.1016/j.gexplo.2016.07.014

14. Tarasevich, Iu. I. (1981). Prirodnye sorbenty v processakh ochistki vody. Kyiv: Naukova dumka, 208.

15. Fu, F., Wang, Q. (2011). Removal of heavy metal ions from wastewaters: A review. Journal of Environmental Management, 92 (3), 407-418. doi: http://doi.org/10.1016/j.jenvman.2010.11.011

16. Akbal, F., Camc1, S. (2010). Comparison of Electrocoagulation and Chemical Coagulation for Heavy Metal Removal. Chemical Engineering \& Technology, 33 (10), 1655-1664. doi: http:/ doi.org/10.1002/ceat.201000091

17. Gavrilescu, M., Pavel, L. V., Cretescu, I. (2009). Characterization and remediation of soils contaminated with uranium. Journal of Hazardous Materials, 163 (2-3), 475-510. doi: http://doi.org/ 10.1016/j.jhazmat.2008.07.103

18. Selvakumar, R., Ramadoss, G., Mridula P. Menon, Rajendran, K. Thavamani, P., Ravi Naidu, Megharaj, M. (2018). Challenges and complexities in remediation of uranium contaminated soils: A review. Journal of Environmental Radioactivity, 192, 592-603. doi: http://doi.org/10.1016/j.jenvrad.2018.02.018

19. Tavengwa, N. T., Cukrowska, E., Chimuka, L. (2014). Preparation, characterization and application of $\mathrm{NaHCO}_{3}$ leached bulk U(VI) imprinted polymers endowed with $\gamma$-MPS coated magnetite in contaminated water. Journal of Hazardous Materials, 267, 221-228. doi: http://doi.org/10.1016/j.jhazmat.2013.12.053

20. Li, P., Wang, J., Wang, X., He, B., Pan, D., Liang, J. et. al. (2018). Arsenazo-functionalized magnetic carbon composite for uranium(VI) removal from aqueous solution. Journal of Molecular Liquids, 269, 441-449. doi: http://doi.org/10.1016/ j.molliq.2018.08.073

21. Misaelides, P. (2011). Application of natural zeolites in environmental remediation: A short review. Microporous and Mesoporous Materials, 144 (1-3), 15-18. doi: http://doi.org/10.1016/ j.micromeso.2011.03.024

22. Misaelides, P. (2019). Clay minerals and zeolites for radioactive waste immobilization and containment. Modified Clay and Zeolite Nanocomposite Materials. Elsevier Inc., 243-274. doi: http:// doi.org/10.1016/b978-0-12-814617-0.00004-9

23. Zhengji, Y. (2010). Microbial removal of uranyl by sulfate reducing bacteria in the presence of Fe (III) (hydr)oxides. Journal of Environmental Radioactivity, 101 (9), 700-705. doi: http:// doi.org/10.1016/j.jenvrad.2010.04.009

24. Tsuruta, T. (2007). Removal and Recovery of Uranium using Microorganisms Isolated from North American Uranium Deposits. American Journal of Environmental Sciences, 3 (2), 60-66. doi: http://doi.org/10.3844/ajessp.2007.60.66

25. Wu, Y., Pang, H., Liu, Y., Wang, X., Yu, S., Fu, D. et. al (2019). Environmental remediation of heavy metal ions by novel-nanomaterials: A review. Environmental Pollution, 246, 608-620. doi: http://doi.org/10.1016/j.envpol.2018.12.076

26. Vareda, J. P., Valente, A. J. M., Durães, L. (2019). Assessment of heavy metal pollution from anthropogenic activities and remediation strategies: A review. Journal of Environmental Management, 246, 101-118. doi: http://doi.org/10.1016/ j.jenvman.2019.05.126 
27. Noubactep, C., Schoner, A., Meinrath, G. (2006). Mechanism of uranium removal from the aqueous solution by elemental iron. Journal of Hazardous Materials, 132 (2-3), 202-212. doi: http://doi.org/10.1016/j.jhazmat.2005.08.047

28. Shin, Y., Bae, S., Lee, W. (2013). Formation of surface mediated iron colloids during $\mathrm{U}(\mathrm{VI})$ and nZVI interaction. Advances in Environmental Research, 2 (3), 167-177. doi: http://doi.org/ 10.12989/aer.2013.2.3.167

29. Duff, M. C., Coughlin, J. U., Hunter, D. B. (2002). Uranium co-precipitation with iron oxide minerals. Geochimica et Cosmochimica Acta, 66 (20), 3533-3547. doi: http://doi.org/ 10.1016/s0016-7037(02)00953-5

30. Jeon, B.-H., Dempsey, B. A., Burgos, W. D., Barnett, M. O., Roden, E. E. (2005). Chemical Reduction of U(VI) by Fe(II) at the Solid-Water Interface Using Natural and Synthetic Fe(III) Oxides. Environmental Science E E Technology, 39 (15), 5642-5649. doi: http://doi.org/10.1021/es0487527

31. Wazne, M., Korfiatis, G. P., Meng, X. (2003). Carbonate Effects on Hexavalent Uranium Adsorption by Iron Oxyhydroxide. Environmental Science E E Technology, 37 (16), 3619-3624. doi: http:// doi.org/10.1021/es034166m

32. Mahoney, J. J., Cadle, S. A., Jakubowski, R. T. (2009). Uranyl Adsorption onto Hydrous Ferric Oxide - A Re-Evaluation for the Diffuse Layer Model Database. Environmental Science \& Technology, 43 (24), 9260-9266. doi: http://doi.org/10.1021/es901586w

33. Gilbert, B., Ono, R. K., Ching, K. A., Kim, C. S. (2009). The effects of nanoparticle aggregation processes on aggregate structure and metal uptake. Journal of Colloid and Interface Science, 339 (2), 285-295. doi: http://doi.org/10.1016/j.jcis.2009.07.058

34. Van der Zee, C., Roberts, D. R., Rancourt, D. G., Slomp, C. P. (2003). Nanogoethite is the dominant reactive oxyhydroxide phase in lake and marine sediments. Geology, 31 (11), 993-996. doi: http://doi.org/10.1130/g19924.1

35. Scwertmann, U., Cornell, R. M. (2000). Iron Oxides in the Laboratory, Preparation and Characterisation. Weinheim: WILEY-VCH Verlag GmbH, 204

36. Rouquerol, F., Rouquerol, J., Sing, K. S., Llewellyn, P., Maurin, G. (2014). Adsorption by powders and porous solids. Elsevier Collection, 646.

37. Delgado, A. V., González-Caballero, F., Hunter, R. J., Koopal, L. K., Lyklema, J. (2007). Measurement and interpretation of electrokinetic phenomena. Journal of Colloid and Interface Science, 309 (2), 194-224. doi: http://doi.org/10.1016/j.jcis.2006.12.075

38. Ohshima, H (1994). A simple expression for Henry's function for the retardation effect in electrophoresis of spherical colloidal particles. Journal of Colloid and Interface Science, 168 269-271. doi: http://doi.org/10.1006/jcis.1994.1419

39. Langmuir, I. (1918). The adsorption of gases on plane surfaces of glass, mica and platinum. Journal of the American Chemical Society, 40 (9), 1361-1403. doi: http://doi.org/10.1021/ ja02242a004

40. Freundlich, H., Heller, W. (1939). The Adsorption ofcis- andtrans-Azobenzene. Journal of the American Chemical Society, 61 (8), 2228-2230. doi: http://doi.org/10.1021/ja01877a071
41. Puigdomènech, I., Colàs, E., Grivé, M., Campos, I., García, D (2014). A tool to draw chemical equilibrium diagrams using SIT Applications to geochemical systems and radionuclide solubility. MRS Proceedings, 1665, 111-116. doi: http://doi.org/ 10.1557/opl.2014.635

42. Brindley, G. W., Brown, G. (1980). Crystal Structures of Clay Minerals and Their X-Ray Identification. London: Mineral. Soc., 496. doi: http://doi.org/10.1180/mono-5

43. Borgnino, L., Avena, M. J., De Pauli, C. P. (2009). Synthesis and characterization of Fe(III)-montmorillonites for phosphate adsorption. Colloids and Surfaces A: Physicochemical and Engineering Aspects, 341 (1-3), 46-52. doi: http://doi.org/10.1016/ j.colsurfa.2009.03.037

44. Yuan, P., Annabi-Bergaya, F., Tao, Q., Fan, M., Liu, Z., Zhu, J et. al. (2008). A combined study by XRD, FTIR, TG and HRTEM on the structure of delaminated Fe-intercalated/pillared clay. Journal of Colloid and Interface Science, 324 (1-2), 142-149. doi: http://doi.org/10.1016/j.jcis.2008.04.076

45. Karnaukhov, A. P. (1999). Adsorbciia. Tekstura dispersnikh i poristikh materialov. Novosibirsk: Nauka. Sib. Predpr. RAN, 470.

46. Leroy, P., Revil, A. (2004). A triple-layer model of the surface electrochemical properties of clay minerals. Journal of Colloid and Interface Science, 270 (2), 371-380. doi: http://doi.org/ 10.1016/j.jcis.2003.08.007

Kovalchuk Iryna, PhD, Senior Researcher, Department of Environmental Chemistry, Institute for Sorption and Problems of Endoecology of National Academy of Sciences of Ukraine, Kyiv, Ukraine, e-mail: kowalchukiryna@gmail.com,ORCID: http://orcid.org/00000002-5687-5530

Tobilko Viktoriia, PhD, Senior Lecturer, Department of Chemical Technology of Ceramics and Glass, National Technical University of Ukraine «Igor Sikorsky Kyiv Polytechnic Institute», Ukraine, e-mail vtobilko@gmail.com, ORCID: http://orcid.org/0000-0002-1800-948X

Kholodko Yurii, Postgraduate Student, Department of Chemical Technology of Ceramics and Glass, National Technical University of Ukraine «Igor Sikorsky Kyiv Polytechnic Institute», Ukraine, e-mail: kholodko.yu@gmail.com, ORCID: http://orcid.org/00000002-2514-767X

Zahorodniuk Nataliia, Department of Chemical Technology of Ceramics and Glass, National Technical University of Ukraine «Igor Sikorsky Kyiv Polytechnic Institute», Ukraine, e-mail: justnatusa@gmail.com, ORCID: http://orcid.org/0000-0002-8856-3873

Kornilozych Borys, Doctor of Chemical Sciences, Professor, Corre sponding Member of NAS Ukraine, Head of Department of Chemical Technology of Ceramics and Glass, National Technical University of Ukraine «Igor Sikorsky Kyiv Polytechnic Institute», Ukraine, e-mail:b kornilovych@kpi.ua,ORCID: http://orcid.org/0000-0002$6393-68 \overline{8} 0$ 